\title{
Bacterioplankton productivity in lakes of the Taylor Valley, Antarctica, during the polar night transition
}

\author{
Trista J. Vick, John C. Priscu* \\ Montana State University, Department of Land Resources and Environmental Science, 334 Leon Johnson Hall, Bozeman, \\ Montana 59717, USA
}

\begin{abstract}
Research on the lakes of the McMurdo Dry Valleys, Antarctica, is typically conducted during the period of $24 \mathrm{~h}$ sunlight (October to January) when logistical support is readily available. As part of the International Polar Year initiative, we obtained logistical support to study microbial dynamics in the permanently ice-covered lakes of the Taylor Valley during the transition from $24 \mathrm{~h}$ of sunlight to the complete darkness of the polar night (mid-April). Our study focused on the perennially ice-covered lakes Fryxell (FRX), East Lobe Bonney (ELB), and West Lobe Bonney (WLB), all of which are chemically stratified and have food webs dominated by microorganisms. Depth-integrated bacterioplankton productivity ( $\mathrm{BP}$; leucine incorporation [Leu] and thymidine incorporation [TdR]) in the lakes ranged from 1.2 to $3.4 \mathrm{mg} \mathrm{C} \mathrm{m}^{-2} \mathrm{~d}^{-1}$. Overall, summer was characterized by relatively high rates of BP and photoautotrophic primary productivity. Rapid decreases in photosynthetically active radiation marked a subsequent transition period, which was characterized by variable cell counts and decreasing Leu:TdR ratios (ratios $>1$ signify a physiological shift from growth to maintenance mode). Finally, cell counts decreased and Leu:TdR increased by as much as $280 \%$ during the fall, revealing a distinct change in the physiological state of the bacterioplankton as light-mediated primary productivity ceased. Our data reveal that the shift in physiological state may result from a switch from contemporary phytoplankton-excreted carbon to other sources of dissolved organic carbon, which can support the bacterioplankton populations through the winter.
\end{abstract}

KEY WORDS: Leucine - Thymidine $\cdot$ Leu:TdR $\cdot$ Dissolved organic carbon · Winter $\cdot$ Loss rates · Survival · Sunlight

Resale or republication not permitted without written consent of the publisher

\section{INTRODUCTION}

High-latitude environments are subject to rapid changes in light intensity during the spring and fall, which are offset by periods of $24 \mathrm{~h}$ daylight or darkness. Antarctic lacustrine ecosystems have been extensively studied during late spring and summer ( October to January), but little is known about the responses of planktonic microorganisms to the spring and fall transition periods or to winter, when complete darkness prohibits photosynthetic activity (Takacs \& Priscu 1998, Priscu et al. 1999). The perennially ice-covered lakes of Taylor Valley (TV), Antarctica, are relatively pristine environments that serve as unique 'natural laboratories' in which to study microbial dynamics in the sensitive polar regions. The lakes contain a paucity of metazoans, are permanently stratified, and host microbial ecosystems sustained largely by microbial loop dynamics (Takacs et al. 2001).

Limnological research in the TV lakes is traditionally conducted during the austral summer, a period characterized by increasing heterotrophic bacterial productivity supported by phytoplankton carbon release, which averages between 5 and $20 \%$ of primary productivity (Sharp 1993, Takacs et al. 2001, Moore 2007), and new carbon entering the lakes via stream flow (Takacs \& Priscu 1998, Priscu et al. 1999). Primary productivity and stream flow meet, on average, 43 and $12 \%$ of total heterotrophic carbon demand 
during the summer, respectively (Takacs et al. 2001), but modeled data show that annual community carbon demand exceeds supply (Priscu et al. 1999, Takacs et al. 2001). Despite the lack of winter data on the TV lakes, several studies have indicated that Antarctic lake microorganisms are adapted to long periods of darkness and rely on various winter survival strategies. Phytoplankton may overwinter in cyst form (Bell \& Laybourn-Parry 1999) or graze on bacterial cells (mixotrophy; Laybourn-Parry 2002, Bielewicz et al. 2011, Thurman et al. 2012), while detection of active heterotrophic bacterioplankton in the TV lakes following 4 mo of complete darkness indicates that heterotrophic activity continues during winter (Takacs \& Priscu 1998) in the absence of photosynthesis. Bacterial communities in lakes of the lower latitude Antarctic Vestfold Hills were found to be active throughout the winter, but, due to decreasing dissolved organic carbon concentrations, bacterial productivity was depressed relative to summer, and unbalanced growth was detected as significant differences in rates of ${ }^{3} \mathrm{H}$-thymidine and ${ }^{3} \mathrm{H}$-leucine uptake (Laybourn-Parry et al. 1995).

Adjustment of growth rates (Garneau et al. 2008), increased metabolic diversity (Grzymski et al. 2012), and/or shifting from active growth to maintenance (Shiah \& Ducklow 1997) may all be important overwintering devices for both heterotrophic and autotrophic organisms at high latitudes. The ratio of ${ }^{3} \mathrm{H}$-leucine (protein production or biomass maintenance) to ${ }^{3} \mathrm{H}$-thymidine (DNA synthesis or reproduction) incorporation rates (Leu:TdR) can reveal changes in rates of bacterial reproduction relative to biomass maintenance, making it a useful metric for understanding how heterotrophic bacteria respond to changing conditions (Chin-Leo \& Kirchman 1990, Shiah \& Ducklow 1997). As growth rates decrease, DNA synthesis has been shown to decline before protein and RNA synthesis (Chin-Leo \& Kirchman 1990), resulting in a higher Leu:TdR and indicating a shift from population growth to survival mode. Shiah \& Ducklow (1997) found that the Leu:TdR ratio was negatively correlated with both temperature and chlorophyll in temperate estuarine habitats, indicating that DNA synthesis increased under regimes of favorable temperature and substrate availability. High Leu:TdR ratios have been found to be associated with slow growth and low bacterial growth efficiency (del Giorgio et al. 2011), suggesting that shifts in the ratio of protein to DNA synthesis provide information about the efficiency of heterotrophic bacterial growth and reproduction. Increasing protein synthesis during winter and fall in other high-latitude lakes
(Laybourn-Parry et al. 1995, Garneau et al. 2008) indicates that shifts from DNA synthesis to protein synthesis may be a key strategy for heterotrophic bacterioplankton overwintering. Given the microbially dominated food webs and the seasonality of new organic carbon input in the TV lakes, heterotrophic activity during the period of winter darkness plays a key role in annual carbon budgets, particularly since photosynthesis:respiration ratios in these lakes have been shown to be $<1$ on an annual basis (Priscu et al. 1999, Takacs et al. 2001).

We hypothesized that heterotrophic bacterial communities in the photic zones of Lakes Fryxell and Bonney are indirectly affected by the transition to winter darkness via the loss of bioavailable organic carbon produced by photosynthetic primary productivity. We expected that the impact of reduced bioavailable organic carbon would manifest as depression of substrate incorporation rates (bulk bacterial productivity) and/or depression of growth rates, indicated by relative increases in Leu:TdR.

\section{MATERIALS AND METHODS}

\section{Study site}

The McMurdo Dry Valleys (MCM; 76 30' $78^{\circ} 00^{\prime} \mathrm{S}$ and $\left.160^{\circ} 00^{\prime}-165^{\circ} 00^{\prime} \mathrm{E}\right)$, which include the $\mathrm{TV}$, have a combined area of $\sim 4200 \mathrm{~km}^{2}$ and comprise the largest ice-free area of the Antarctic continent $(\sim 1 \%)$. The region is a cold desert, with annual mean temperatures near $-20^{\circ} \mathrm{C}$ (Doran et al. 2002) and annual precipitation not exceeding $50 \mathrm{~mm}$ water equivalent (Fountain et al. 2009). The landscape is characterized by a composite of glaciers, dry soils, ephemeral streams, and perennially ice-covered lakes. The perennial ice cover on the lakes, which ranges from 3 to $5 \mathrm{~m}$ thick, inhibits wind-induced mixing of the water column and restricts atmospheric gas exchange (Priscu 1997, Spigel \& Priscu 1998). The lack of wind-driven turbulence, along with low advective stream flow, allows vertically stable water columns with strong physical and chemical gradients to persist throughout the year. The vertical gradients provide organisms with a variety of nutrient, temperature, and redox conditions, promoting strong stratification of organisms over the water column (e.g. Roberts et al. 2004b).

Our study focused on the photic zone of 3 lakes: Lake Fryxell (FRX; $19 \mathrm{~m}$ deep), the east lobe of Lake Bonney $\left(\mathrm{ELB}_{i} \sim 40 \mathrm{~m}\right.$ deep), and the west lobe of Lake Bonney (WLB; $40 \mathrm{~m}$ deep). A sill at $13 \mathrm{~m}$ 
divides Lake Bonney into east and west lobes and effectively inhibits exchange of deep sub-chemocline water between ELB and WLB (Spigel \& Priscu 1998). We divided the water columns of each of the lake basins into discrete layers based on oxygen concentrations (Fig. 1). The combined epi- and metalimnia span the photic zone of each lake, which is the layer most directly influenced by seasonal transitions in sunlight.

\section{Sampling procedures}

Samples were collected and analyzed according to procedures established by the Priscu Research Group as part of the McMurdo Long-Term Ecological Research Program (MCM LTER; http://mcmlter.org/ queries/lakes/lakes_home.jsp). Procedures are summarized briefly below.

Sampling holes (50 to $70 \mathrm{~cm}$ diameter) were melted in the ice cover over the deepest portion of each lake. All depths reported were measured from the piezometric water level in the sampling hole. Samples were collected with clean Niskin bottles (with PTFEcoated components) 4 times between November 2007 and February 2008 and at approximately weekly intervals between March and April 2008 and stored near $4^{\circ} \mathrm{C}$ in insulated containers until analysis at lakeside laboratories (within $4 \mathrm{~h}$ ). Samples for primary productivity, cell counts, chlorophyll a ( chl a), $\mathrm{N}, \mathrm{P}$, dissolved organic carbon (DOC), and $\mathrm{O}_{2}$ were collected at $5,6,7,8,9,10,11$, and $12 \mathrm{~m}$ in FRX $; 4,5$, $6,8,10,11,13,15,18,20$, and $22 \mathrm{~m}$ in ELB; and 4,5 , $6,8,10,12,13,14,15$, and $17 \mathrm{~m}$ in WLB. Samples for bacterial productivity were collected from the same depths except for 7 and $12 \mathrm{~m}$ in FRX; $6,8,12$, and $22 \mathrm{~m}$ in $\mathrm{ELB}_{\text {; }}$ and 6,8 , and $12 \mathrm{~m}$ in WLB.

\section{Physical and chemical measurements}

Temperature and conductivity were measured with an SBE 25 Sealogger CTD as outlined by Spigel \& Priscu (1998). Underwater photosynthetically active radiation (PAR) was measured during primary productivity (PPR) incubations using a LI-COR LI-193SA spherical quantum sensor, and logged with a LI-COR Model 1000 data logger (LI-COR Biosciences). The sensor was placed $10 \mathrm{~m}$ below the surface of the ice in ELB and WLB, and $7 \mathrm{~m}$ below the ice in FRX. Samples for macronutrients $\left(\mathrm{NO}_{3}{ }^{-}, \mathrm{NO}_{2}{ }^{-}, \mathrm{NH}_{4}{ }^{+}\right.$, and soluble reactive phosphorous, SRP) were prepared for analysis as described by Priscu (1995) and measured using a Lachat autoanalyzer; method detection limits were: $\mathrm{NO}_{3}{ }^{-}=0.4 \mu \mathrm{g} \mathrm{N} \mathrm{I}^{-1} ; \mathrm{NO}_{2}{ }^{-}=0.3 \mu \mathrm{g} \mathrm{N} \mathrm{I}^{-1} ; \mathrm{NH}_{4}{ }^{+}=$ $0.7 \mu \mathrm{g} \mathrm{N} \mathrm{l}^{-1}$; SRP $=0.3 \mu \mathrm{g} \mathrm{l}^{-1}$. Samples for DOC were filtered through combusted and acidleached $25 \mathrm{~mm}$ GF/F filters into acid washed and combusted $125 \mathrm{ml}$ amber borosilicate glass bottles with PTFElined caps, acidified to $\mathrm{pH} \sim 2$ with $6 \mathrm{~N} \mathrm{HCl}$, and stored at $4^{\circ} \mathrm{C}$ until analysis. DOC was determined using a Shimadzu TOC-V Series total organic carbon analyzer. Dissolved oxygen was measured using the azide modification of the mini-Winkler titration (limit of detection $=0.09 \mathrm{mg} \mathrm{O}_{2} \mathrm{l}^{-1}$; APHA 1995). Dissolved inorganic carbon was measured by infrared gas analysis of acid sparged samples.

\section{Biological parameters}

PPR was measured as described by Lizotte et al. (1996) by incubating duplicate light and a single dark sample in situ at selected depths for $24 \mathrm{~h}$ with ${ }^{14} \mathrm{C}$-labeled bicarbonate (specific activity $55 \mathrm{mCi} \mathrm{mmol}^{-1}$ ) to final isotope
Fig. 1. Vertical profiles of temperature, conductivity, and oxygen $\left(\mathrm{O}_{2}\right)$ in the water columns of Lake Fryxell (FRX), and the east (ELB) and west (WLB) lobes of Lake Bonney, Antarctica, during March 2008. The panels show the thickness of the ice cover, the epilimnion (EPI), and the metalimnion (META) in each lake. Phototrophic primary productivity occurs only at depths above and including the metalimnia in all lakes 
concentrations ranging from 0.18 to $0.38,0.17$ to 0.53 , and 0.17 to $0.50 \mu \mathrm{Ci} \mathrm{ml}^{-1}$ for FRX, ELB, and WLB, respectively. The final ${ }^{14} \mathrm{C}$-bicarbonate additions were adjusted to account for highly variable dissolved inorganic carbon levels through the water columns of these lakes. Following incubation, samples were transported in the dark to lakeside laboratories where they were immediately filtered onto Whatman GF/F filters in the dark. The filters were placed in $20 \mathrm{ml}$ scintillation vials, acidified with $0.5 \mathrm{ml}$ of $3 \mathrm{~N} \mathrm{HCl}$, and dried at $60^{\circ} \mathrm{C}$. Radioactive label retained in the cellular residue on the filters was counted on a calibrated scintillation counter. A submersible spectrofluorometer (bbe Moldaenke Fluoroprobe ${ }^{\circledR}$ ) was used to provide high vertical resolution $(\sim 10 \mathrm{~cm})$ estimates of total chl a concentration (Beutler et al. 2002).

Heterotrophic bacterial productivity (BP) was measured using $\left[{ }^{3} \mathrm{H}\right]$ methyl-thymidine incorporation into DNA (Fuhrman \& Azam 1982) and [ $\left.{ }^{3} \mathrm{H}\right]$ leucine incorporation into protein (Kirchman et al. 1985). Samples (1.5 ml; 3 live and 2 killed with trichloroacetic acid, TCA) were incubated with $20 \mathrm{nM}$ of radio-labeled thymidine (specific activity $20 \mathrm{Ci} \mathrm{mmol}^{-1}$ ) or leucine (specific activity $84 \mathrm{Ci} \mathrm{mmol}^{-1}$ ) at 2 to $4^{\circ} \mathrm{C}$ in the dark for $20 \mathrm{~h}$. Separate experiments showed that incorporation was linear under these conditions. Incubations were terminated by the addition of $100 \%$ cold TCA (5\% final). Following centrifugation, a series of extractions with cold 5\% TCA and cold $80 \%$ ethanol were performed and the final centrifuged pellet was dried overnight at room temperature. Radioactivity in the samples was determined by standard scintillation spectroscopy. Thymidine and leucine incorporation rates ( $\mathrm{nM}$ TdR $\mathrm{d}^{-1}$ or $\mathrm{nM}$ Leu $\mathrm{d}^{-1}$ ) at incubation temperature (logged during incubations) were converted to rates at in situ temperatures using energy of

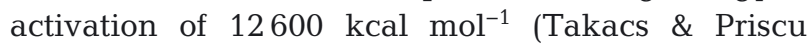
1998). Rates were converted to bacterial carbon productivity using $2.0 \times 10^{18}$ cells mol ${ }^{-1}$ thymidine (Bell

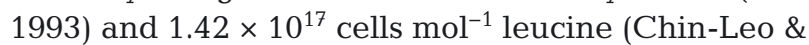
Kirchman 1988) and a cellular carbon content of $11 \mathrm{fg}$ C cell ${ }^{-1}$ (Kepner et al. 1998). Leu:TdR represents the molar ratio of incorporation of these 2 compounds (Shiah \& Ducklow 1997). Bacterial cells fixed in sodium borate buffered formalin (5\% v/v) were enumerated via epifluorescence microscopy following staining with SYBR Gold on black $0.2 \mu \mathrm{m}$ polycarbonate membrane filters (Lisle \& Priscu 2004). At least 10 fields and 300 cells were counted per sample.

The following forward difference model, based on average bacterial cell losses and gains, was used to determine bacterial dynamics during the sampling period (Jassby \& Goldman 1974):

$$
B L=B P_{\text {cell }}-\mathrm{d} B / \mathrm{d} t
$$

where $B L$ is equal to the bacterial loss/gain rate (cells $\mathrm{m}^{-2} \mathrm{~d}^{-1}$; positive values indicate loss and negative values indicate gain), $B P_{\text {cell }}$ is equal to heterotrophic BP (cells $\mathrm{m}^{-2} \mathrm{~d}^{-1}$ ), $B$ is the standing stock of cells measured by epifluorescence microscopy (cells $\mathrm{m}^{-2}$ ), and $t$ is time (days). Depth integration was not weighted for lake morphometry and represents integrated gains and losses under $1 \mathrm{~m}^{2}$ for each layer at the sampling site only. $B$ was determined by direct cell counts. To determine $B P_{\text {cell, }}$ we converted bacterial thymidine and leucine incorporation rates (nM $\mathrm{TdR}^{-1}$ or $\mathrm{nM}$ Leu $\mathrm{d}^{-1}$ ) to bacterial cell productivity (cells $\mathrm{m}^{-2} \mathrm{~d}^{-1}$ ) using the conversion factors described previously. $B P_{\text {cell }}$ was calculated using the following equation:

$$
B P_{\text {cell }}=0.5\left(B P_{\text {cell } i}+B P_{\text {cell } i+1}\right)
$$

where $B P_{\text {celli }}$ and $B P_{\text {celli }+1}$ are equal to BP at successive sample points. $\mathrm{d} B / \mathrm{d} t$ is equal to:

$$
\mathrm{d} B / \mathrm{d} t=\left(B_{i+1}-B_{i}\right) / \Delta t
$$

where $B_{i}$ and $B_{i+1}$ are equal to $B$ at successive sampling points. Specific loss/gain rates $\left(\mathrm{d}^{-1}\right)$ were determined by dividing $B L$ by $B$ for the corresponding interval. Turnover times (days) represent the reciprocal of specific loss rate.

\section{Statistical analyses}

Statistical analyses were conducted using the $\mathrm{R}$ software package (www.r-project.org) or Sigma Plot ${ }^{\circledR}$. Data were checked for normality (ShapiroWilk test; $p>0.05$ ) and constant variance before analysis and were log-transformed where the assumptions were not satisfied. Seasonal comparisons were conducted using Student's $t$-test or the MannWhitney test to account for unequal sample sizes, 1way analysis of variance (ANOVA), or 1-way ANOVA on ranks. Correlation coefficients (r) represent Pearson product-moment correlation.

\section{RESULTS}

\section{Physical limnology}

Water temperatures ranged from 2.1 to $2.6^{\circ} \mathrm{C},-2.1$ to $4.9^{\circ} \mathrm{C}$, and -4.4 to $2.1^{\circ} \mathrm{C}$ in FRX, ELB, and WLB, respectively. On average, the epilimnetic temperatures in FRX $\left(2.5^{\circ} \mathrm{C}\right)$ and WLB $\left(1.7^{\circ} \mathrm{C}\right)$ were warmer 
than the metalimnetic temperatures $\left(\mathrm{FRX}, 2.2^{\circ} \mathrm{C}\right.$; WLB,$-0.03^{\circ} \mathrm{C}$ ). The opposite was true in ELB, where epilimnetic and metalimnetic temperatures averaged 3.5 and $4.8^{\circ} \mathrm{C}$, respectively. Average conductivity was relatively low in the epilimnia of each lake (2.9 to $7.2 \mathrm{mS} \mathrm{cm}{ }^{-1}$ ), increased in the metalimnia (5.8 to $56.6 \mathrm{mS} \mathrm{cm}^{-1}$ ), and was about an order of magnitude lower in FRX than in ELB and WLB. No significant temporal changes in conductivity or temperature occurred during the season in any of the lakes $(p>$ 0.05; Fig. 1), which corroborates the decadal-scale stability of the water columns of these lakes shown by Spigel \& Priscu (1998).

The first sunset of the season occurred on 20 February. We divided the study period into 3 intervals based on changes in PAR: (1) summer (November to mid-February), (2) transitional period (mid-February to mid-March), and (3) fall (March to early April). Summer was characterized by either increasing (FRX $2.6 \% \mathrm{~d}^{-1}, \mathrm{p}=0.003$ ) or relatively stable PAR (ELB, $-0.3 \% \mathrm{~d}^{-1} ; \mathrm{WLB}-0.6 \% \mathrm{~d}^{-1}$ ) PAR. The significant increase in FRX PAR was presumably due to thinning ice cover (data not shown). The subsequent transition was a period of comparatively rapid change where PAR decreased by $2.4 \% \mathrm{~d}^{-1}$ (FRX and ELB), and $3.1 \% \mathrm{~d}^{-1}$ (WLB). PAR continued to decrease during the fall in ELB $\left(-3.8 \% \mathrm{~d}^{-1}\right.$; Table 1$)$ and began to stabilize in FRX and WLB (0.0003 and 0.7\% $\mathrm{d}^{-1}$, respectively), with seasonal minima at sensor depth in late March and early April (Table 1, see Figs. 2 to $4 \& 6$ ).

\section{Chemical and biological limnology}

Dissolved oxygen was supersaturated in the epilimnetic layers of all lakes, reaching 257, 392, and $366 \%$ of air saturation (Fig. 1). Much of this oxygen has been shown to originate from freeze concentration as new lake ice forms at the underside of the permanent ice cover (Craig et al. 1992). Oxygen levels drop precipitously through the metalimnia in all lakes and approach suboxic levels below the chemocline, a depth which also coincides with the bottom of the photic zone. Nutrient concentrations were relatively consistent in the lakes throughout the season

Table 1. Linear regression slopes of biological and physical parameters versus day of the year for Lake Fryxell (FRX), and the east (ELB) and west (WLB) lobes of Lake Bonney, Antarctica. Trends are divided into summer (November to mid-February), transition (mid-February to mid-March), and fall (mid-March to April) periods based on rates of change in photosynthetically active radiation (PAR; see discussion in 'Results'). Lake layers, Epi: epilimnion, Meta: metalimnion. TdR: thymidine incorporation; Leu: leucine incorporation; L:T: molar ratio of Leu to TdR; Cells: bacterial cell densities $\left(\times 10^{10}\right)_{\text {; }}$ PPR: primary productivity; DOC: dissolved organic carbon; chl a: chlorophyll $a_{i}$ SRP: soluble reactive phosphorus; DIN: dissolved inorganic nitrogen; N:P: mass ratio of DIN to SRP. Asterisks indicate regressions with $\mathrm{p} \leq 0.05$. Regressions were not performed for Leu during the summer because only 2 data points were collected

\begin{tabular}{|c|c|c|c|c|c|c|c|c|c|c|c|}
\hline Lake layer & $\mathrm{TdR}$ & Leu & L:T & Cells & PPR & DOC & Chl a & SRP & DIN & $\mathrm{N}: \mathrm{P}$ & PAR \\
\hline \multicolumn{12}{|l|}{ Summer } \\
\hline FRX Epi & 0.005 & - & - & 0.8 & 0.007 & 0.05 & -0.05 & 0.03 & -0.007 & -0.004 & $0.07^{*}$ \\
\hline FRX Meta & 0.004 & - & - & 0.5 & 0.03 & 0.2 & -0.01 & 0.6 & 1.6 & -0.006 & \\
\hline ELB Epi & 0.002 & - & - & -0.7 & 0.05 & 0.001 & 0.04 & -0.2 & -3.5 & 0.7 & -0.04 \\
\hline ELB Meta & 0.001 & - & - & -0.1 & -0.05 & 0.03 & -0.002 & 0.003 & -11.3 & -0.7 & \\
\hline WLB Epi & $0.007^{*}$ & - & - & 4.4 & 0.1 & 0.05 & $0.2^{*}$ & -0.1 & $-5.9^{*}$ & 0.3 & -0.03 \\
\hline WLB Meta & -0.0004 & - & - & -0.008 & -0.03 & 0.04 & $0.04^{*}$ & 0.08 & $-8.9^{*}$ & -1.2 & \\
\hline \multicolumn{12}{|l|}{ Transition } \\
\hline FRX Epi & -0.01 & -0.02 & 0.09 & 7.1 & -0.2 & 0.04 & $0.2^{*}$ & -0.4 & -0.2 & 0.04 & -0.2 \\
\hline FRX Meta & 0.02 & 0.007 & 0.05 & 3.5 & -0.04 & 0.01 & -0.04 & -0.8 & 2.8 & 0.02 & \\
\hline ELB Epi & 0.01 & -0.003 & -0.04 & 1.8 & -0.5 & -0.07 & $0.3^{*}$ & -0.09 & -6.4 & 0.4 & -0.3 \\
\hline ELB Meta & 0.005 & -0.0009 & -0.2 & 0.07 & -0.03 & -0.5 & 0.05 & 0.2 & 4.7 & -0.4 & \\
\hline WLB Epi & -0.03 & 0.004 & -0.4 & -8.6 & $-0.6^{*}$ & -0.2 & 0.2 & 0.1 & 2.3 & -1.2 & $-0.1^{*}$ \\
\hline WLB Meta & 0.02 & 0.00001 & -1.3 & -0.1 & -0.02 & -3.0 & -0.09 & -0.7 & -10.1 & $9.6^{*}$ & \\
\hline \multicolumn{12}{|l|}{ Fall } \\
\hline FRX Epi & -0.001 & -0.004 & 0.05 & -8.7 & -0.06 & -0.03 & -0.004 & 0.3 & 0.08 & -0.06 & 0.00004 \\
\hline FRX Meta & -0.05 & -0.01 & 0.3 & -1.3 & -0.02 & $0.07^{*}$ & -0.02 & 1.46 & 0.02 & -0.1 & \\
\hline ELB Epi & -0.02 & 0.02 & 1.7 & -2.7 & -0.2 & 0.005 & 0.2 & 0.1 & 2.6 & -1.0 & -0.09 \\
\hline ELB Meta & -0.005 & 0.01 & 2.6 & 0.07 & -0.03 & 0.08 & -0.005 & -0.1 & -8.0 & -0.07 & \\
\hline WLB Epi & $-0.05^{*}$ & $-0.04^{*}$ & 1.1 & -4.0 & -0.001 & 0.2 & 0.02 & -0.2 & -4.2 & 0.8 & 0.001 \\
\hline WLB Meta & -0.004 & -0.009 & 2.3 & -0.05 & -0.02 & 0.2 & -0.1 & 0.02 & -14.2 & -1.6 & \\
\hline
\end{tabular}


(see Figs. 2 to 4). DOC peaks usually occurred in February and concentrations increased during the fall (Table 1), while SRP and dissolved inorganic nitrogen (DIN; $\mathrm{NO}_{3}{ }^{-}+\mathrm{NO}_{2}{ }^{-}+\mathrm{NH}_{4}{ }^{+}$) were generally high in the epilimnia at the beginning of summer and decreased during the season (Table 1), suggesting dominance of biological DOC productivity and drawdown of inorganic nutrients during summer (Lizotte et al. 1996). Summer decreases in $N$ were significant in the epi- and metalimnion of WLB ( $p=0.003$ and $\mathrm{p}=0.03$, respectively; Table 1 ).

PPR maxima occurred in summer (late January and mid-February) and then decreased rapidly during the transition period (see Figs. 2 to 4 ; Table 1 ) to seasonal minima (epilimnia: 0.1 to $2.9 \mathrm{mg} \mathrm{C} \mathrm{m}^{-2} \mathrm{~d}^{-1}$, metalimnia: 0.08 to $0.1 \mathrm{mg} \mathrm{C} \mathrm{m}^{-2} \mathrm{~d}^{-1}$; see Figs. 2 to 4 ) during the fall. Chl a reached maximum concentrations (all-lake epilimnetic average $=35.8 \mathrm{mg} \mathrm{m}^{-2}$ ) in the fall (Fig. 2) and overall, increased significantly in the epilimnia (FRX: $\mathrm{r}^{2}=0.5, \mathrm{p}=0.03$; ELB: $\mathrm{r}^{2}=0.8, \mathrm{p}<$ 0.001; WLB: $\left.\mathrm{r}^{2}=0.9, \mathrm{p}<0.001\right)$ while concentrations decreased in the FRX metalimnion $\left(\mathrm{r}^{2}=0.5, \mathrm{p}=0.02\right)$ and did not change significantly in the other 2 lakes (Figs. 2 to 4). Decoupling of PPR from chl a concentration could result from increasing chl a content per cell in response to decreasing PAR (Desortová 1981, Felip \& Catalan 2000) or indicative of the overwinter maintenance of photochemical apparatus in the absence of active PPR suggested by Morgan-Kiss et al. (2006).

PPR was positively correlated with PAR across the study season in all of the lakes (FRX metalimnion: $\mathrm{r}=$ $0.7, \mathrm{p}=0.04$; ELB epi- and metalimnion: $\mathrm{r}=0.7, \mathrm{p}=$ $0.02, \mathrm{r}=0.9, \mathrm{p}<0.01$; WLB epi- and metalimnion: $\mathrm{r}=$ $0.08, \mathrm{p}<0.01, \mathrm{r}=0.7, \mathrm{p}=0.02$ ), while chl $\mathrm{a}$ and PAR were negatively correlated in all 3 epilimnia (FRX, $\mathrm{r}=-0.8, \mathrm{p}=0.003 ;$ ELB, $\mathrm{r}=-1.0, \mathrm{p}<0.001 ; \mathrm{WLB}, \mathrm{r}=$ $-0.9, p<0.001)$. PPR was not correlated with BP or cell densities in any of the lakes ( $p>0.05)$, indicating that the 2 processes are not coupled on a seasonal basis. Bulk BP was not significantly different among summer, the transition period, or fall, and was not correlated with any of the environmental parameters that we measured.

\section{Lake Fryxell}

Over the course of the season, FRX epilimnetic TdR (log-transformed) was positively correlated with PAR $(\mathrm{r}=0.7, \mathrm{p}=0.03)$ and negatively correlated with chl $a$ $(r=-0.7, p=0.02)$. Leu and TdR increased in the FRX epilimnion during summer and peaked in early December, similar to DIN. TdR decreased before the PPR peak after the sunset, and covaried with SRP and DIN starting in March (Fig. 2A,B). Chl a increased by
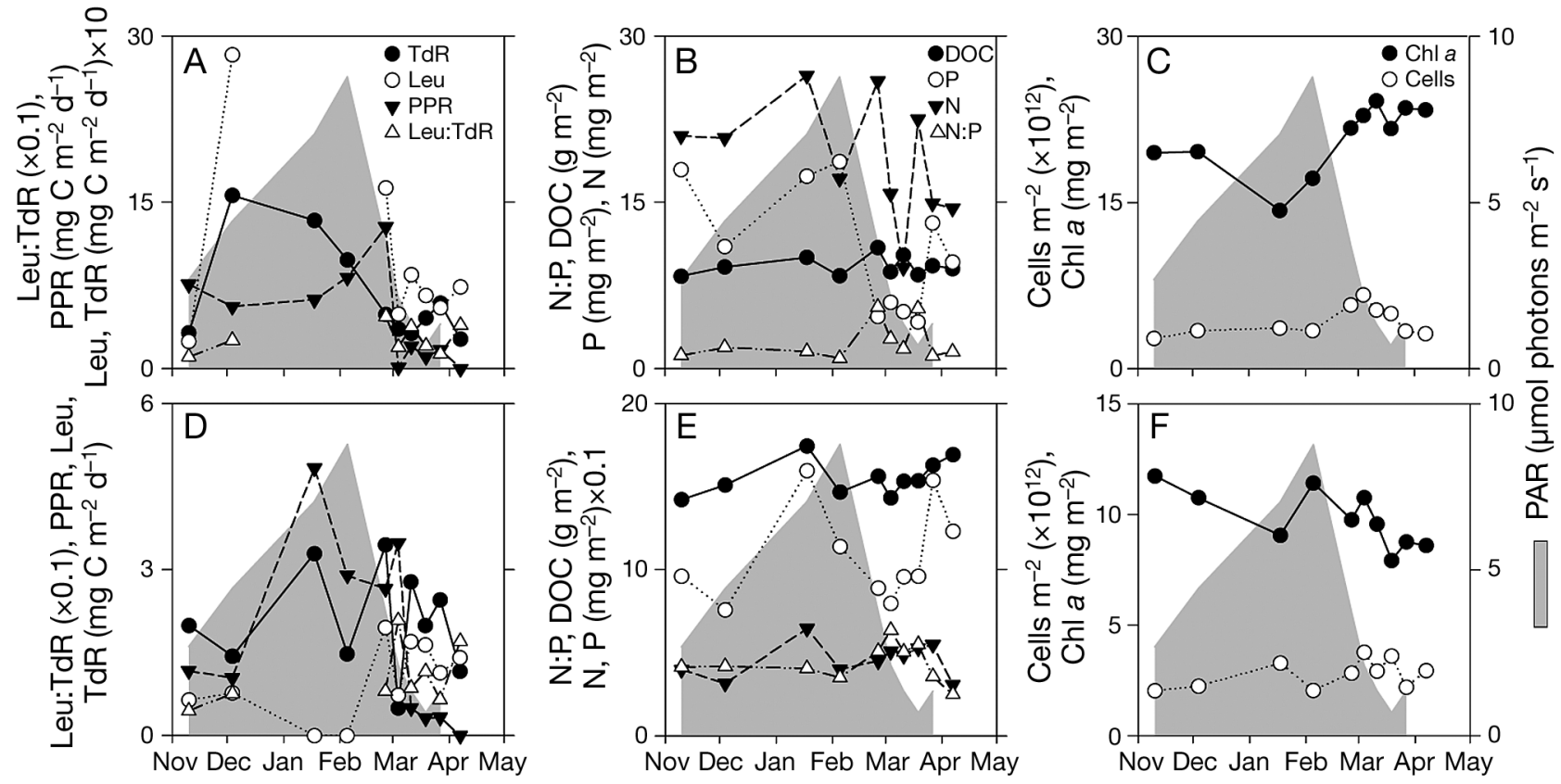

Fig. 2. Seasonal nutrients, activity, and bacterial biomass in Lake Fryxell, Antarctica. (A-C) Epilimnion. (D-F) Metalimnion. N: $\mathrm{NO}_{3}{ }^{-}+\mathrm{NO}_{2}{ }^{-}+\mathrm{NH}_{4}{ }^{+}$, P: soluble reactive phosphorus, Chl a: chlorophyll a, DOC: dissolved organic carbon, TdR: thymidine, Leu: leucine, PPR: primary productivity, PAR: photosynthetically active radiation. Leu:TdR is the ratio of leucine to thymidine incorporation rates $\left(\mathrm{nmol} \mathrm{m}^{2} \mathrm{~h}^{-1}\right)$. N:P is by mass. Note differences in scales as indicated by axis labels 
$20.0 \%$ from November to April, with a significant increase occurring during the transition period $(\mathrm{p}=$ 0.001 ) even though PPR deceased at a rate of $2.2 \%$ $\mathrm{d}^{-1}$ during the same interval.

In the metalimnion, PPR, DIN, SRP, TdR, and DOC covaried during the summer (Fig. 2B,D,E). All peaked during summer by 15 January, except for TdR, which reached maximum along with Leu, just after PAR began to decrease during the transition period. PPR peaked again during the transition on 5 March at the same time that Leu and TdR abruptly decreased. Cell counts did not change during the 5 March decrease in $\mathrm{BP}$, indicating that the change was due to a decrease in activity per cell, rather than a loss of biomass. SRP, DIN, and DOC ( $p=0.04$; Table 1$)$ increased during the fall, while PPR decreased rapidly $\left(12.2 \% \mathrm{~d}^{-1}\right)$ after the 5 March peak and stayed low for the remainder of the season. At the same time, Leu increased and then stabilized, leading to a fall escalation in the Leu:TdR ratio (Fig. 2D, Table 1).

\section{East Lobe of Lake Bonney}

During summer, PPR, TdR, and chl a covaried in the ELB epilimnion. After the sunset, PPR decreased until the end of the season at an average rate of $12.2 \% \mathrm{~d}^{-1}$. Chl a increased significantly during this transition $(\mathrm{p}=0.04$; Table 1$)$ and continued to in- crease until the final sampling point. TdR and Leu decreased during the transition by 35.1 and $46.5 \%$, respectively, between 27 February and 4 March. Similar to FRX, cell counts did not change during this time, indicating variation in cell specific activity. TdR then rose to the seasonal maximum before decreasing into the fall, while Leu continued to increase and reached the seasonal maximum during the fall (April). Although both metrics showed variability in $\mathrm{BP}$, the general trend was similar to that of chl a late in the season. Leu:TdR increased at a rate of $3.4 \% \mathrm{~d}^{-1}$ during the fall (Fig. 3A).

TdR, chl $a$, and PPR covaried with P in the metalimnion during summer, but PPR began to decrease at the start of the transition and continued until the final sample point. TdR increased approaching the transition, but dropped (64.7\%) along with Leu $(51.0 \%)$ on 4 March due to an apparent decrease in activity per cell. Both Leu and TdR recovered after 4 March and covaried with chl a until late March and early April, when Leu:TdR increased due to a drop in TdR (Fig. 3A,C).

\section{West Lobe of Lake Bonney}

TdR increased during the summer in the epilimnion ( $p=0.02$; Table 1$)$, but did not reach a maximum (1 March) until the transition, 1 mo after the

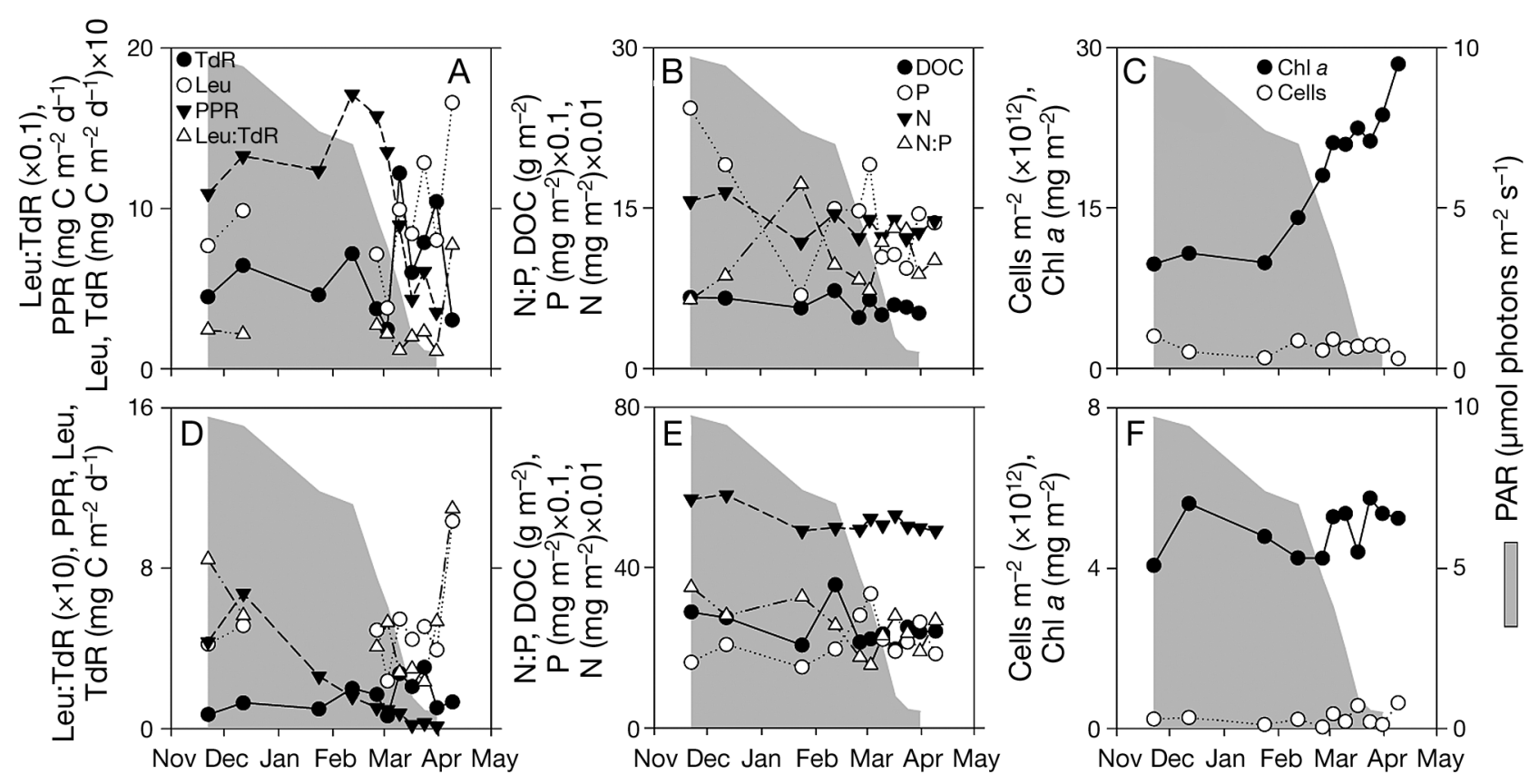

Fig. 3. Seasonal nutrients, activity, and bacterial biomass in the east lobe of Lake Bonney, Antarctica. (A-C) Epilimnion. (D-F) Metalimnion. Abbreviations as in Fig. 2. Note differences in scales as indicated by axis labels 

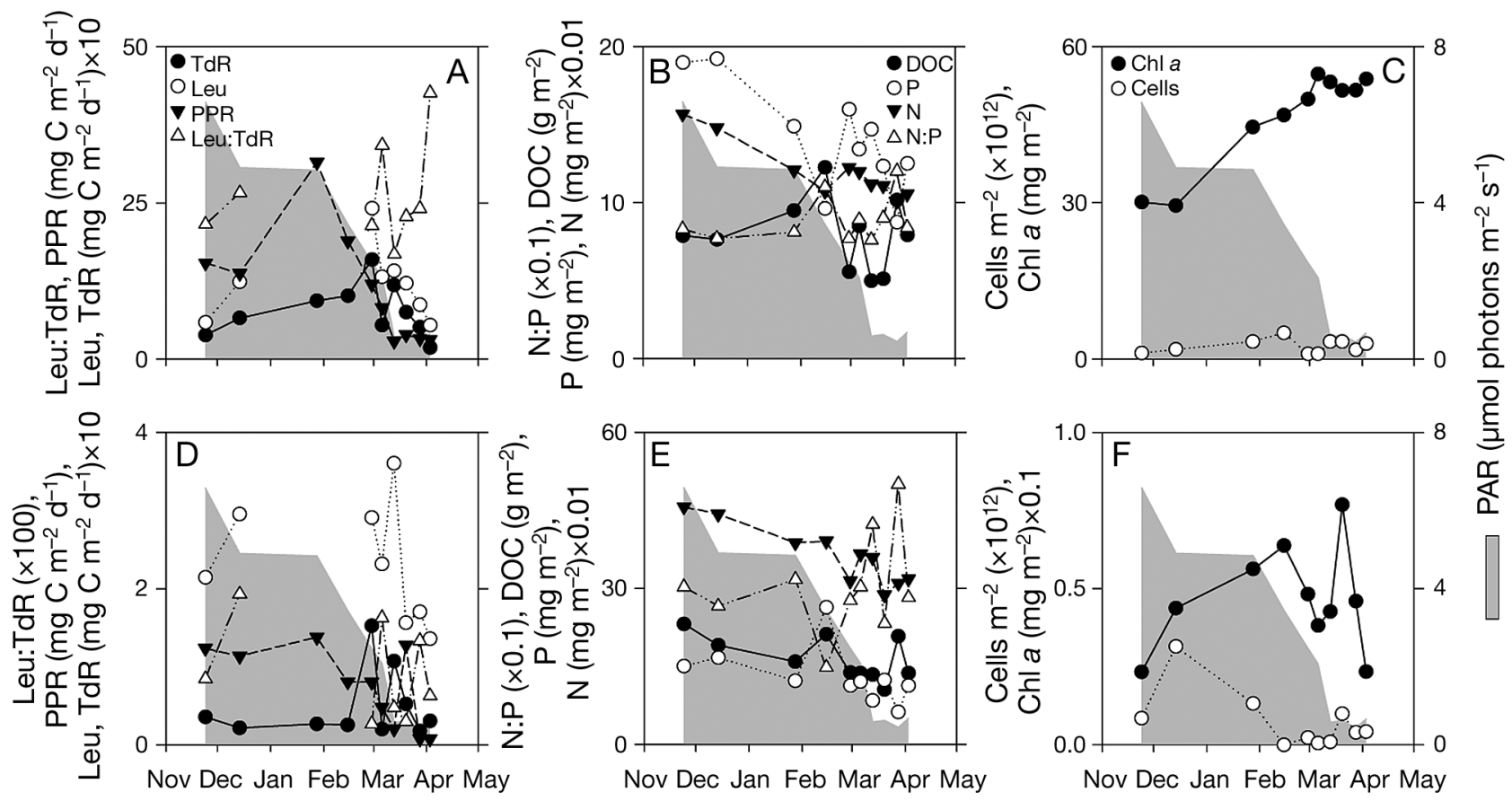

Fig. 4. Seasonal nutrients, activity, and bacterial biomass in the west lobe of Lake Bonney, Antarctica. (A-C) Epilimnion. (D-F) Metalimnion. Abbreviations as in Fig. 2. Note differences in scales as indicated by axis labels

PPR peak (Fig. 4A). The TdR peak coincided with a peak in Leu and $\mathrm{P}$, and a $54.6 \%$ decrease in DOC. Following this maximum, TdR and Leu decreased quickly for $1 \mathrm{wk}$ (66.0 and $45.6 \%$, respectively), coincident with seasonal low cell counts and seasonal high chl $a$. TdR and Leu slowly decreased through fall $(p=0.009$ and $p=0.008$, respectively; Table 1$)$. The magnitude of the decrease was greater for TdR, causing Leu:TdR to increase during fall. DOC and chl a trended upward during the fall period, as biological activity declined (Table 1, Fig. 4A-C).

TdR peaked in the metalimnion on 1 March, following a peak in DOC and SRP, and then decreased along with Leu (86.7 and $20.6 \%$, respectively) until 7 March. The drop in Leu and TdR corresponded with seasonal low cell counts, decreasing PPR, and decreasing chl $a$. Both TdR and Leu peaked again on 14 March in advance of a PPR peak, and then all 3 decreased and remained relatively stable for the rest of the season (Table 1, Fig. 4D-F).

\section{Bacterioplankton dynamics}

Pooled bacterial abundance in FRX, ELB, and WLB decreased by $1.3 \%$ for every $1 \%$ increase in Leu: $\mathrm{TdR}$, indicating that Leu:TdR effectively predicts bacterial growth in these lakes $\left(\mathrm{r}^{2}=0.36, \mathrm{p}<0.0001\right.$;
Fig. 5), despite their different physicochemical environments (e.g. Fig. 1). Leu:TdR and bacterial abundance were positively related in FRX, although cell densities only increased by $0.34 \%$ for every $1 \%$ increase in Leu:TdR $\left(r^{2}=0.42 ; \mathrm{p}=0.007\right.$; regression not shown), indicating that cell numbers were increasing more quickly than expected based on Leu:TdR.

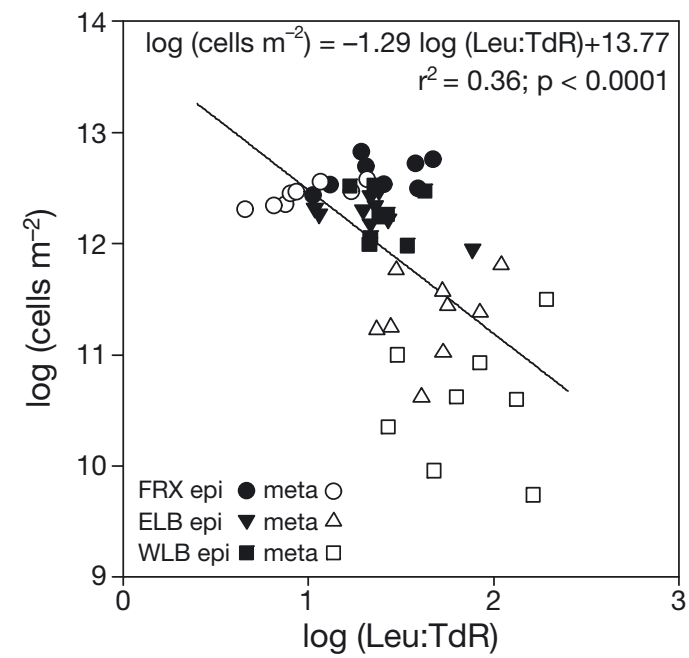

Fig. 5. Log-log relationship between the ratio of leucine to thymidine incorporation rates (Leu:TdR) and cell densities for Lake Fryxell (FRX), and the east (ELB) and west (WLB) lobes of Lake Bonney, Antarctica. EPI: epiliminion, META: metalimnion. The solid line is the result of linear regression $(\mathrm{n}=50)$ 

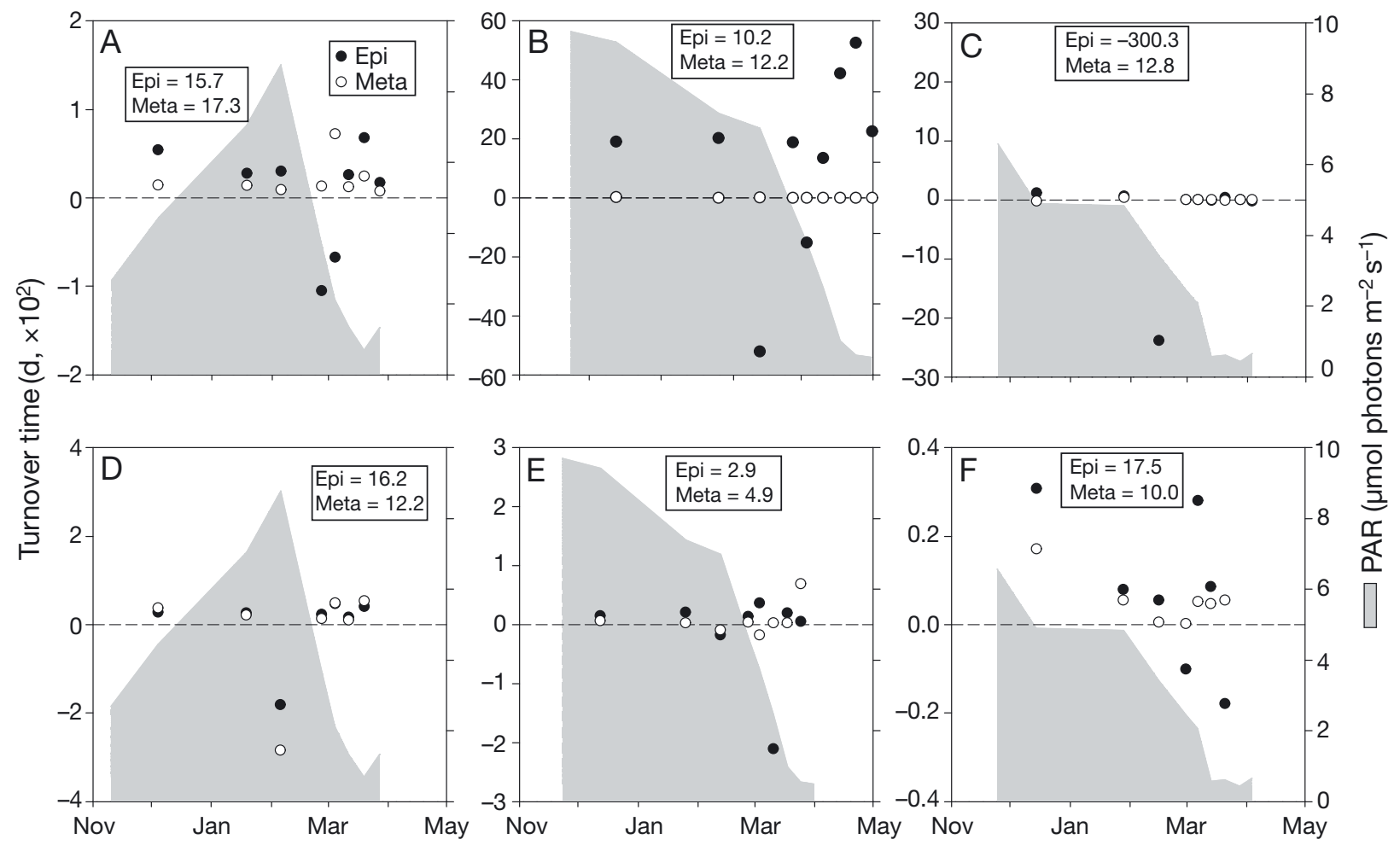

Fig. 6. Season-long bacterial turnover times shown with photosynthetically active radiation (PAR). Turnover times are the reciprocal of specific loss rate, calculated based on (A-C) thymidine (TdR) or (D-F) leucine (Leu) incorporation. The dashed line indicates a steady state where bacterial carbon gains equal losses. Negative (positive) turnover times denote the replacement time required for bacterial carbon to increase (decrease). (A, D) Lake Fryxell, (B, E) east lobe of Lake Bonney, (C, F) west lobe of Lake Bonney, Antactica. Epi: epiliminion; Meta: metalimnion. Boxed values indicate temporally-weighted average turnover times (days) over the period of measurement

Overall, Leu:TdR was $>1$ in all 3 lakes throughout the sampling period and increased during the fall (Figs. 2 to 4 , Table 1).

Bacterial turnover times computed from the output of our forward difference model (Eqs. 1 to 3 ) ranged from -284 to $69 \mathrm{~d}$ (Leu) and -5208 to $5263 \mathrm{~d}$ (TdR), indicating slow growth and loss of bacterial carbon overall. Negative turnover represents the amount of time required for bacterial carbon to increase, whereas positive turnover times indicate the time required to lose an equivalent amount of bacterial carbon. Losses of bacterial cells were fastest in the metalimnion of each lake during the transition in March (FRX Leu $\sim 10 \mathrm{~d}$; WLB Leu $\sim 6 \mathrm{~h}$ ) and February (ELB TdR $\sim 4$ d). In FRX, gains in biomass occurred during the transition period. Biomass gains also occurred in ELB during the transition within 2 wk following the first sunset. Conversely, losses (Leu) were recorded in WLB immediately after the sunset. Overall, biomass losses dominated the sampling period, and occurred over periods of between 2.9 and $17.5 \mathrm{~d}$ (temporally-weighted average losses; Fig. 6).

\section{DISCUSSION}

A key hypothesis addressed by our study is that heterotrophic bacterial communities in MCM lakes are indirectly affected by the onset of winter darkness via the loss of bioavailable organic carbon from photosynthetic PPR. The coupling of heterotrophic bacterial metabolism with phytoplankton photosynthesis is a key component of the conventional view of the microbial loop (Azam et al. 1983). Previous studies have shown that bacterioplankton productivity in MCM lakes increases along with phytoplankton productivity during summer (Takacs \& Priscu 1998, Takacs et al. 2001), despite the fact that DOC budgets indicate the ultimate limitation of bacterioplankton growth by DOC if phytoplankton excretion is the only available carbon source (Takacs et al. 2001). Overall, we found that heterotrophic productivity is decoupled from PPR in these lakes during fall and that bacterioplankton communities switch from growth to maintenance as the sun sets for the polar night. 


\section{Temporal patterns and bottom-up controls on bacterial productivity}

Morán et al. (2010) showed statistical evidence for phytoplankton mediated bottom-up control in NE Atlantic Shelf waters by regression between leucine incorporation rate and $\mathrm{chl} a$, while others have shown that bacterioplankton activity covaries with PPR, inferring linkages between phytoplankton-produced organic matter and heterotrophic bacterial growth (e.g. Gasol et al. 1998, Shiah 1999, Ruiz-González et al. 2012). We were only able to detect statistically insignificant covariation between BP and PPR in the epilimnia during the summer; the 2 processes were decoupled after the sunset. This decoupling may result from bacterioplankton growth limitation yearround by factors other than phytoplankton-derived organic carbon, with the most likely being temperature and inorganic nutrients (Ward \& Priscu 1997, Dore \& Priscu 2001). Another explanation is that changes in the quantity or quality of DOC inputs due to changes in the types of DOC excreted by phytoplankton, reliance on chemoautotrophically produced carbon, and/or pulses of DOC from increased rates of cell lysis allowed continued bacterial activity into the polar night, but changed its efficiency (Apple \& del Giorgio 2007). Similarly, bacterioplankton may have switched from reliance on phytoplanktonderived organic carbon to other carbon sources within the lakes, most notably the decomposition of particulate organic matter or the bulk DOC pool (Takacs et al. 2001). Finally, top-down controls may confound the connection between substrate availability and BP (Thingstad et al. 1997). We will discuss each of these possibilities in turn.

\section{Temperature and inorganic nutrients}

Bacteria in the TV lakes grow at temperatures well below their optima (Ward \& Priscu 1997, Vick 2010), and stable year-round temperature profiles likely lead to persistent slow growth. Such perennial temperature limitation may obscure a direct link between PPR and heterotrophic activity; however, the seasonal vertical stability of vertical lake temperature (Fig. 1) indicates that temperature alone cannot explain the uncoupling we observed after the sunset. Past research has also demonstrated the importance of phosphorus deficiency to both bacterioplankton and phytoplankton in the lakes (Priscu 1995, Takacs \& Priscu 1998, Dore \& Priscu 2001). Bacterioplankton can be impacted by competition with phytoplankton for inorganic nutrients, although heterotrophs have been shown to more successfully utilize scarce or less-nutritious carbon sources during periods of darkness (Kuipers et al. 2000). In our study, N:P ratios converged on the Redfield ratio (7:1 by mass; Redfield 1958) later in the season, especially in ELB and WLB, suggesting more balanced nutrient availability. Relief from even minor nutrient limitation due to decreased competition with phytoplankton could play an important role in allowing BP rates to recover after the sunset.

\section{Variation in DOC sources}

The amount and quality of carbon excreted by phytoplankton has been shown to vary with rates of PPR as well as other environmental conditions (Bratbak \& Thingstad 1985, Baines \& Pace 1991, Obernosterer \& Herndl 1995, Magaletti et al. 2004), and substrate quality has been shown to be an important regulator of bacterioplankton growth (Apple \& del Giorgio 2007, Lee et al. 2009). Säwström et al. (2008a) showed that decreases in the amount and quality of available carbon substrate correlate with increased proportions of bacterial cells with leaky membranes in other polar lakes, which may provide a pulse of labile organic carbon to the system. Thurman et al. (2012) detected significant predation by nanoflagellates on bacterioplankton in TV lakes during the transition to winter, a phenomenon that was also shown to increase the availability of dissolved organic matter and drive bacterial activity at night in the Mediterranean Sea (Ruiz-González et al. 2012). Pulses of labile organic carbon from leaky bacterial cells and grazing after the sunset may partially explain the increases in BP that we observed later in the transition period in all lakes (Figs. 2 to 4 ).

The abundance and activity of chemoautotrophic Archaea have been shown to increase during the winter in coastal waters of the Antarctic Peninsula (Grzymski et al. 2012, Williams et al. 2012), pointing to an important role for dark $\mathrm{CO}_{2}$ fixation during the polar night. Summer dark $\mathrm{CO}_{2}$ fixation in the metalimnion of Lake Fryxell provides up to $40 \%$ as much carbon as photosynthetic PPR (1.2 $\mathrm{mg} \mathrm{C} \mathrm{m} \mathrm{m}^{2} \mathrm{~d}^{-1}$; our unpubl. data), which is enough to account for up to $23 \%$ of estimated bacterial carbon demand in Lake Fryxell (Takacs et al. 2001). Such chemoautotrophically fixed $\mathrm{CO}_{2}$ would be produced year round, and while little is known about rates of excretion or quality of released DOM in this environment, dark $\mathrm{CO}_{2}$ fixation may play an important role in balancing the 
annual carbon budget of TV lakes, particularly those such as Lakes Fryxell and Bonney, where appropriate redox gradients exist to fuel chemotrophic productivity (Lee et al. 2004).

The deep, saline waters of Lakes Fryxell and Bonney contain legacy pools of organic matter that are available to bacterioplankton growing above the chemocline through upward diffusion (Priscu et al. 1999). Assuming that this entire pool is bioavailable, it would meet $\leq 5 \%$ of estimated bacterial carbon demand (Takacs et al. 2001). Approximately $20 \%$ of the bulk DOC pool is comprised of low molecular weight fulvic material thought to be readily accessible to bacteria (McKnight et al. 1991). Estimates of bacterial carbon demand based on season average Leu and estimated bacterial respiration rates in the epilimnia of the TV lakes (Takacs et al. 2001) indicate that there is adequate labile DOC (assuming no input to the DOC pool) to last just over $1 \mathrm{yr}$ in FRX, 9 mo in $\mathrm{ELB}$, and $10 \mathrm{mo}$ in WLB. In the metalimnion, where DOC concentrations are higher, this increases to $1.5 \mathrm{yr}$ in FRX and just over $4 \mathrm{yr}$ in ELB and WLB.

Bacterial decomposition of particulate organic matter provides another carbon source in the TV lakes. Based on the C:chl ratio calculated for ELB phytoplankton by Sharp (1993; $\left.70 \mathrm{~g} \mathrm{C} \mathrm{g}^{-1} \mathrm{chl}\right)$ and the chl $a$ concentration in ELB at the 10 April sampling point $\left(28 \mathrm{mg} \mathrm{m}^{-2}\right.$ ), a total of $1.96 \mathrm{~g} \mathrm{C} \mathrm{m}^{-2}$ was present as phytoplankton particulate during the fall. Using the bacterial decomposition rate $\left(0.032 \% \mathrm{~d}^{-1}\right)$ measured by Priscu (1992) for ELB, this carbon pool would last $\sim 31 \mathrm{~d}$, assuming no growth of phytoplankton biomass, variation in the $\mathrm{C}: \mathrm{chl}$, or changes in bacterial activity. Collectively, these results show that the bulk DOC pool may be the most important source of energy for BP after the cessation of PPR during the fall. This pool will be replenished to a small degree by upward diffusion of legacy DOC and freeze-out as lake water forms new lake ice during winter.

\section{Top-down controls on bacterial productivity}

The interval of fastest modeled bacterial growth $(\mathrm{d} B / \mathrm{d} t$; Eq. 3$)$ occurred during the transition period, concurrent with the waning of summer PPR rather than during the summer (Fig. 6), supporting the idea that $\mathrm{d} B / \mathrm{d} t$ is not mediated by phytoplankton-produced carbon alone. Periods of predicted loss were more common than periods of predicted gain, and modeled results agreed with measured $\mathrm{BP}$ on a lake-to-lake basis. In FRX, modeled growth in late February (Fig. 6) was validated by increased cell concentrations during March (Fig. 2). However, predicted growth in ELB and WLB was not reflected by actual cell counts. This discrepancy is indicative of losses of bacterioplankton not accounted for by changes in growth rate. Advective loss is negligible in these lakes due to lack of outflow, making other losses such as sinking, predation by protists, and viral lysis relatively important mechanisms of bacterial loss. Either sinking or decomposition must follow physiological cell death to remove dead cells from the water column, but planktonic sinking rates are low in the TV lakes (Priscu 1992, Takacs \& Priscu 1998), and decomposition of organic matter is also slow owing to the low temperature, making physiological cell death alone an unlikely explanation for the fast losses of bacterioplankton recorded during the transition and fall periods.

Protist grazing on bacteria in TV lakes has been studied primarily during the summer and has been shown to be relatively low (Bell \& Laybourn-Parry 1999, Roberts et al. 2004a). Thurman et al. (2012) showed that phototrophic nanoflagellates (PNAN) ingested heterotrophic bacteria in TV lakes during the fall, and that increased PNAN grazing rates corresponded with decreased rates of $\mathrm{BP}$, particularly in WLB. Interestingly, the post-sunset decrease in bacterial cell counts that we observed in the WLB metalimnion coincided with a period of decreasing $\mathrm{chl} a$ concentrations (Fig. 4), supporting the idea that mixotrophic protists may have switched from photosynthesis to heterotrophy (Hansen et al. 2000).

Viral lysis is another important cause of bacterial loss in TV lakes (Lisle \& Priscu 2004, Säwström et al. 2008b). Studying north temperate lakes, Maurice et al. (2010) found that peak numbers of damaged bacterial cells corresponded to minimum rates of lysogeny during the winter. Their results indicate that lysogens were induced by slowing host metabolic rates to replicate their genome and 'abandon ship' before conditions worsened. The TV lakes contain high concentrations of virus-like particles $\left(10^{6} \mathrm{ml}^{-1}\right.$; Kepner et al. 1998), and a large proportion of lysogenic bacteria (63\% of the total population; Lisle \& Priscu 2004), which could explain the losses in ELB and WLB that could not be accounted for by our model.

\section{Physiological responses of bacterioplankton}

Typically, cells with high Leu:TdR ratios are thought to be incorporating carbon to sustain cellular processes, but not reproducing (e.g. Shiah \& Ducklow 1997). We found an overall negative relationship between Leu:TdR and bacterial cell densities (Fig. 5), 
showing that across the 3 lakes, Leu:TdR is a good predictor of bacterial reproduction. Leu:TdR was lowest on average in FRX (FRX $=18.6, \mathrm{ELB}=39.7, \mathrm{WLB}=$ 59.1; Figs. 2 to 4 ) indicating that, relative to ELB and WLB, populations in FRX were growing rapidly. Similarly, bacterial cell densities in FRX increased more rapidly than predicted by Leu:TdR, although the increase in cell density per unit Leu:TdR was low ( $0.34 \%$ per $1 \%$ increase in Leu:TdR). A positive relationship between cell density and Leu:TdR is counter to the usual assumption that cells with high Leu:TdR ratios are utilizing carbon but are not reproducing, thus exhibiting lower bacterial growth efficiency. One solution to this conundrum is that bacterioplankton in FRX are dividing, but also have high bacterial growth efficiency relative to those in ELB and WLB (Takacs et al. 2001) and are therefore respiring less leucine than expected (del Giorgio et al. 2011). FRX is nutrient replete compared to ELB and WLB (Figs. 2 to 4), which could explain higher growth efficiency.

In all lakes, Leu:TdR increased after the first sunset and again at the sample point closest to winter. The transition to polar night led to the cessation of PPR, which infers changes in the nature of the major carbon source for bacterial growth (Morán et al. 2010). Bacterioplankton forced to switch to less desirable carbon substrates may have down-regulated reproduction in response to the more oligotrophic winter environment. Alternatively, bacterial community composition may have changed to favor organisms more adapted to winter conditions (Alonso-Sáez et al. 2008), which may incorporate Leu and TdR differently than the summer community and/or have lower bacterial growth efficiency.

\section{CONCLUSIONS}

Data from our study indicate that bacterioplankton in Lakes Fryxell and Bonney remain active throughout the fall transition period, are dynamically coupled with phytoplankton productivity during the summer, and likely switch focus from growth to maintenance as the sun sets in austral winter. Takacs \& Priscu (1998) showed that bacterioplankton are active in these lakes during early spring before the onset of PPR, and together these data indicate that heterotrophic activity is likely maintained at low levels throughout the austral polar night. During this winter period, the lakes would enter a period of net heterotrophy, where the bulk DOC pool and upward diffusion from the deep pool of legacy DOC may become more important in supporting biological activity.
Acknowledgements. We thank the 2007-2008 McMurdo LTER limnology team for assistance with sample collection and processing, and J. Dore for helpful comments on an earlier version of this manuscript. This work was funded by NSF grants OPP-1115254, OPP-0838953, and OPP- 0839075 to J.C.P. and represents part of T.J.V.'s MS thesis work. The Montana Space Grant Consortium provided additional funding for T.J.V. We also thank 3 anonymous reviewers and the Editor for helpful comments on an earlier version of this manuscript.

\section{LITERATURE CITED}

Alonso-Sáez L, Sánchez O, Gasol JM, Balagué V, PedrósAlio C (2008) Winter-to-summer changes in the composition and single-cell activity of near-surface Arctic prokaryotes. Environ Microbiol 10:2444-2454

APHA (American Public Health Association) (1995) Standard methods, 19th edn. American Public Health Association, Washington, DC

Apple JK, del Giorgio PA (2007) Organic substrate quality as the link between bacterioplankton carbon demand and growth efficiency in a temperate salt-marsh estuary. ISME J 1:729-742

Azam F, Fenchel T, Field JG, Gray JS, Meyer-Reil LA, Thingstad F (1983) The ecological role of watercolumn microbes in the sea. Mar Ecol Prog Ser 10: 257-263

Baines SB, Pace ML (1991) The production of dissolved organic matter by phytoplankton and its importance to bacteria: patterns across marine and freshwater systems. Limnol Oceanogr 36:1078-1090

Bell RT (1993) Estimating production of heterotrophic bacterioplankton via incorporation of tritiated thymidine. In: Kemp PF, Sherr BF, Sherr EB, Cole JJ (eds) Handbook of methods in aquatic microbial ecology. Lewis Publishers, Ann Arbor, MI, p 495-503

Bell EM, Laybourn-Parry J (1999) Annual plankton dynamics in an Antarctic saline lake. Freshw Biol 41:507-519

> Beutler M, Wiltshire KH, Meyer B, Moldaenke C and others (2002) A fluorometric method for the differentiation of algal populations in vivo and in situ. Photosynth Res 72: 39-53

> Bielewicz S, Bell E, Kong W, Friedberg I, Priscu JC, MorganKiss R (2011) Protist diversity in a permanently ice-covered Antarctic lake during the polar night transition. ISME J 5:1559-1564

Bratbak G, Thingstad TF (1985) Phytoplankton-bacteria interactions: an apparent paradox? Analysis of a model system with both competition and commensalism. Mar Ecol Prog Ser 25:23-30

$>$ Chin-Leo G, Kirchman D (1988) Estimating bacterial production in marine waters from the simultaneous incorporation of thymidine and leucine. Appl Environ Microbiol 54:1934-1939

Chin-Leo G, Kirchman DL (1990) Unbalanced growth in natural assemblages of marine bacterioplankton. Mar Ecol Prog Ser 63:1-8

> Craig H, Wharton RA, McKay CP (1992) Oxygen supersaturation in ice-covered Antarctic lakes: biological versus physical contributions. Science 255:318-321

> Del Giorgio P, Condon R, Bouvier T, Longnecker K, Bouvier C, Sherr E, Gasol J (2011) Coherent patterns in bacterial growth, growth efficiency, and leucine metabolism along 
a northeastern Pacific inshore-offshore transect. Limnol Oceanogr 56:1-16

> Desortová B (1981) Relationship between chlorophyll- $\alpha$ concentration and phytoplankton biomass in several reservoirs in Czechoslovakia. Int Rev Hydrobiol 66: 153-169

> Doran PT, McKay CP, Clow GD, Dana GL, Fountain AG, Nylen T, Lyons WB (2002) Valley floor climate observations from the McMurdo Dry Valleys, Antarctica, 19862000. J Geophys Res 107:4772-4784

> Dore JE, Priscu JC (2001) Phytoplankton phosphorus deficiency and alkaline phosphatase activity in the McMurdo Dry Valley lakes, Antarctica. Limnol Oceanogr 46:1331-1346

> Felip M, Catalan J (2000) The relationship between phytoplankton biovolume and chlorophyll in a deep oligotrophic lake: decoupling in their spatial and temporal maxima. J Plankton Res 22:91-106

Fountain AG, Nylen T, Monaghan A, Basagic HJ, Bromwich D (2009) Snow in the McMurdo Dry Valleys, Antarctica. Int J Climatol 30:633-642

> Fuhrman JA, Azam F (1982) Thymidine incorporation as a measure of heterotrophic bacterioplankton production in marine surface waters - evaluation and field results. Mar Biol 66:109-120

Garneau MÈ, Roy S, Lovejoy C, Gratton Y, Vincent WF (2008) Seasonal dynamics of bacterial biomass and production in a coastal arctic ecosystem: Franklin Bay, western Canadian Arctic. J Geophys Res 113:C07S91, doi: 10.1029/2007JC004281

Gasol JM, Doval MD, Pinhassi J, Calderón-Paz JI, GuixaBoixareu N, Vaqué D, Pedrós-Alió C (1998) Diel variations in bacterial heterotrophic activity and growth in the northwestern Mediterranean Sea. Mar Ecol Prog Ser 164:107-124

Grzymski J, Riesenfeld C, Williams T, Dussaq A and others (2012) A metagenomic assessment of winter and summer bacterioplankton from Antarctic Peninsula coastal surface waters. ISME J 6:1901-1915

> Hansen PJ, Skovgaard A, Glud RN, Stoeker DK (2000) Physiology of the mixotrophic dinoflagellate Fragilidium subglobsum. II. Effects of time scale and prey concentration on photosynthetic performance. Mar Ecol Prog Ser 201: 137-146

> Jassby AD, Goldman CR (1974) Loss rates from a lake phytoplankton community. Limnol Oceanogr 19:618-627

Kepner RL, Wharton RA, Suttle CA (1998) Viruses in Antarctic lakes. Limnol Oceanogr 43:1754-1761

Kirchman D, K'Nees E, Hodson R (1985) Leucine incorporation and its potential as a measure of protein synthesis by bacteria in natural aquatic systems. Appl Environ Microbiol 49:599-607

Kuipers B, van Noort GJ, Vosjan J, Herndl GJ (2000) Diel periodicity of bacterioplankton in the euphotic zone of the subtropical Atlantic Ocean. Mar Ecol Prog Ser 201: $13-25$

Laybourn-Parry J (2002) Survival mechanisms in Antarctic lakes. Philos Trans R Soc Lond B Biol Sci 357:863-869

Laybourn-Parry J, Bayliss P, Ellis-Evans JC (1995) The dynamics of heterotrophic nanoflagellates and bacterioplankton in a large ultra-oligotrophic Antarctic lake. J Plankton Res 17:1835-1850

> Lee CW, Bon CW, Hii YS (2009) Temporal variation of bacterial respiration and growth efficiency in tropical coastal waters. Appl Environ Microbiol 75:7594-7601
Lee P, Mikucki J, Foreman C, Priscu JC and others (2004) Thermodynamic constraints on microbially mediated processes in lakes of the McMurdo Dry Valleys, Antarctica. Geomicrobiol J 21:221-237

> Lisle JT, Priscu JC (2004) The occurrence of lysogenic bacteria and microbial aggregates in the lakes of the McMurdo Dry Valleys, Antarctica. Microb Ecol 47:427-439

- Lizotte MP, Sharp TR, Priscu JC (1996) Phytoplankton dynamics in the stratified water column of Lake Bonney, Antarctica: biomass and productivity during the winterspring transition. Polar Biol 16:155-162

> Magaletti E, Urbani R, Sist P, Ferrari CR, Cicero AM (2004) Abundance and chemical characterization of extracellular carbohydrates released by the marine diatom Cylindrotheca fusiformis under N- and P-limitation. Eur J Phycol 39:133-142

> Maurice CF, Bouvier T, Comte J, Guillemette F, Del Giorgio PA (2010) Seasonal variations of phage life strategies and bacterial physiological states in three northern temperate lakes. Environ Microbiol 12:628-641

McKnight DM, Aiken GR, Smith RL (1991) Aquatic fulvic acids in microbially based ecosystems: results from two desert lakes in Antarctica. Limnol Oceanogr 36: 998-1006

Moore JM (2007) Diversity, productivity, and physiology of microorganisms in the stream-moat-lake transition of Lake Bonney, Antarctica. MS thesis, Montana State University, Bozeman, MT

Morán XAG, Calvo-Díaz A, Ducklow HW (2010) Total and phytoplankton mediated bottom-up control of bacterioplankton change with temperature in NE Atlantic shelf waters. Aquat Microb Ecol 58:229-239

> Morgan-Kiss RM, Priscu JC, Pocock T, Gudynaite-Savitch L, Hunter NP (2006) Adaptation and acclimation of photosynthetic microorganisms to permanently cold environments. Microbiol Mol Biol Rev 70:222-252

Obernosterer I, Herndl GJ (1995) Phytoplankton extracellular release and bacterial growth: dependence on the inorganic N:P ratio. Mar Ecol Prog Ser 116:247-257

Priscu JC (1992) Particulate organic matter decomposition in the water column of Lake Bonney, Taylor Valley, Antarctica. Antarct J US 27:260-262

> Priscu JC (1995) Phytoplankton nutrient deficiency in lakes of the McMurdo dry valleys, Antarctica. Freshw Biol 34: 215-227

Priscu JC (1997) The biogeochemistry of nitrous oxide in permanently ice-covered lakes of the McMurdo Dry Valleys, Antarctica. Global Change Biol 3:301-305

Priscu JC, Wolf CF, Takacs CD, Fritsen CH and others (1999) Carbon transformations in a perennially ice-covered Antarctic lake. Bioscience 49:997-1008

Redfield AC (1958) The biological control of chemical factors in the environment. Am Sci 46:205-211

Roberts EC, Priscu JC, Laybourn-Parry J (2004a) Microplankton dynamics in a perennially ice-covered Antarctic lake - Lake Hoare. Freshw Biol 49:853-869

Roberts EC, Priscu JC, Wolf C, Lyons WB, Laybourn-Parry J (2004b) The distribution of microplankton in the McMurdo Dry Valley Lakes, Antarctica: response to ecosystem legacy or present-day climatic controls? Polar Biol 27:238-249

Ruiz-González C, Lefort T, Massana R, Simó R, Gasol JM (2012) Diel changes in bulk and single-cell bacterial heterotrophic activity in winter surface waters of the northwestern Mediterranean Sea. Limnol Oceanogr 57:29-42 
Säwström C, Pearce I, Davidson AT, Rosén P, LaybournParry J (2008a) Influence of environmental conditions, bacterial activity and viability on the viral component in 10 Antarctic lakes. FEMS Microbiol Ecol 63:12-22

Säwström C, Lisle J, Anesio AM, Priscu JC, Laybourn-Parry $\mathrm{J}$ (2008b) Bacteriophage in polar inland waters. Extremophiles 12:167-175

Sharp TR (1993) Temporal and spatial variation of light, nutrients, and phytoplankton production in Lake Bonney, Antarctica. MS thesis, Montana State University, Bozeman, MT

Shiah FK (1999) Diel cycles of heterotrophic bacterioplankton abundance and production in the ocean surface waters. Aquat Microb Ecol 17:239-246

Shiah FK, Ducklow HW (1997) Bacterioplankton growth responses to temperature and chlorophyll variations in estuaries measured by thymidine:leucine incorporation ratio. Aquat Microb Ecol 13:151-159

Spigel RH, Priscu JC (1998) Physical limnology of the McMurdo Dry Valley lakes. In: Priscu JC (ed) Ecosystem dynamics in a polar desert: the McMurdo Dry Valleys, Antarctica. Antarctic Research Series. American Geophysical Union, Washington, DC, p 153-187

Takacs CD, Priscu JC (1998) Bacterioplankton dynamics in the McMurdo Dry Valley lakes, Antarctica: production

Editorial responsibility: Hugh Ducklow, Woods Hole, Massachusetts, USA and biomass loss over four seasons. Microb Ecol 36: 239-250

Takacs CD, Priscu JC, McKnight DM (2001) Bacterial dissolved organic carbon demand in McMurdo Dry Valley Lakes, Antarctica. Limnol Oceanogr 46:1189-1194

Thingstad T, Hagström A, Rassoulzadegan F (1997) Accumulation of degradable DOC in surface waters: Is it caused by a malfunctioning microbial loop? Limnol Oceanogr 42:398-404

Thurman J, Parry J, Hill PJ, Priscu JC, Vick TJ, Chiuchiolo A, Laybourn-Parry J (2012) Microbial dynamics and flagellate grazing during transition to winter in Lakes Hoare and Bonney, Antarctica. FEMS Microbiol Ecol 82: $449-458$

Vick T (2010) Bacterioplankton dynamics in stratified lakes of the McMurdo Dry Valleys, Antarctica during the transition to Polar Night. MS thesis, Montana State University, Bozeman, MT

Ward BB, Priscu JC (1997) Detection and characterization of denitrifying bacteria from a permanently ice-covered Antarctic Lake. Hydrobiologia 347:57-68

Williams T, Long E, Evans F, DeMaere M and others (2012) A metaproteomic assessment of winter and summer bacterioplankton from Antarctic Peninsula coastal surface waters. ISME J 6:1883-1900

Submitted: February 13, 2012; Accepted: October 16, 2012 Proofs received from author(s): December 6, 2012 